\title{
IKLIM ORGANISASI DAN KOMITMEN ORGANISASI TERHADAP KEDISIPLINAN KERJA PEGAWAI PADA KANTOR SEKRETARIAT DPRD KABUPATEN BIMA
}

Firmansyah Kusumayadi', Muhammad Ali ${ }^{2}$

${ }^{1}$ Program Studi Manajemen, Sekolah Tinggi Ilmu Ekonomi (STIE) Bima

E-mail :firmansyah90.stiebima@gmail.com

2Sekolah Tinggi Ilmu Ekonomi (STIE) Bima

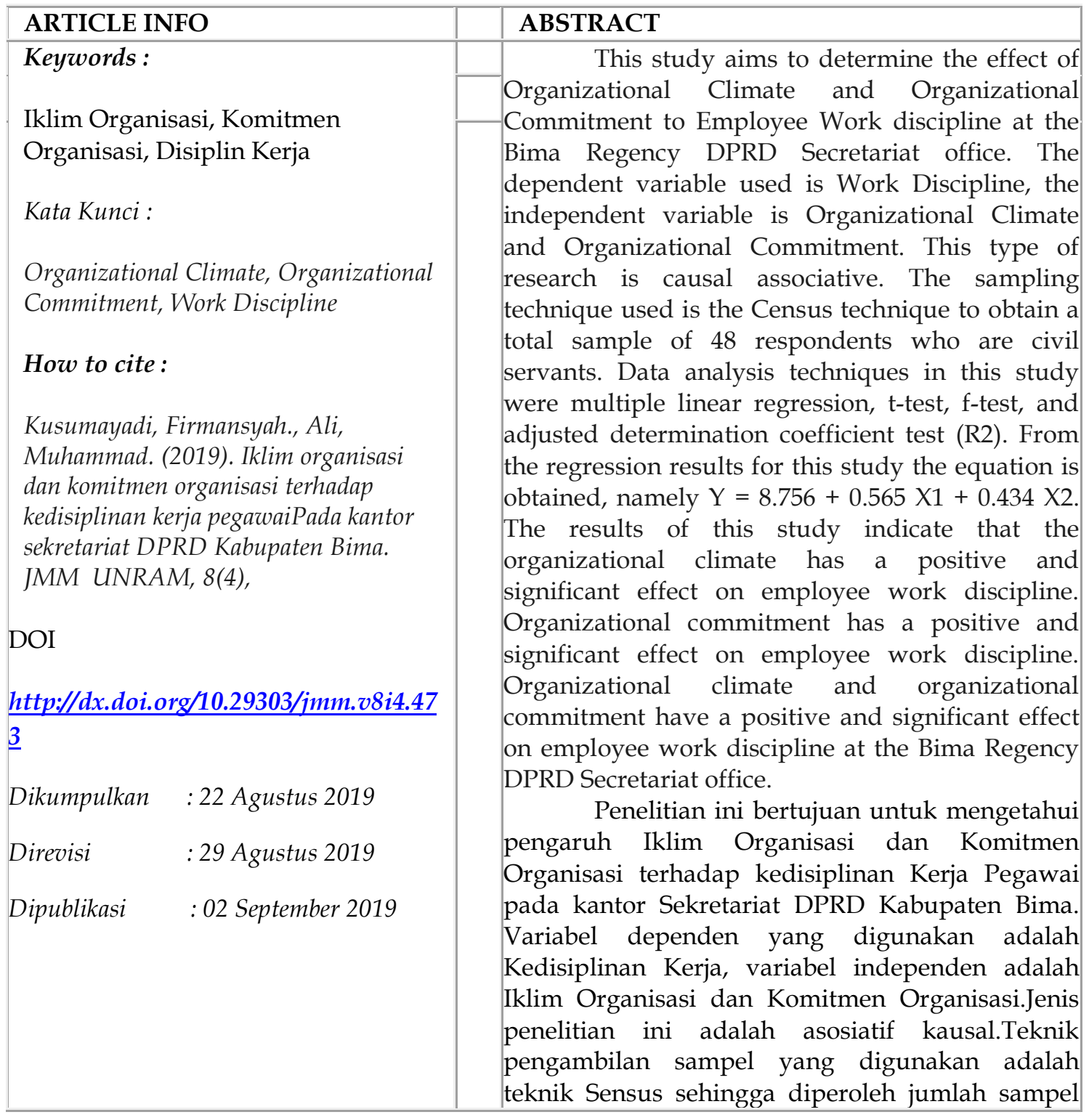




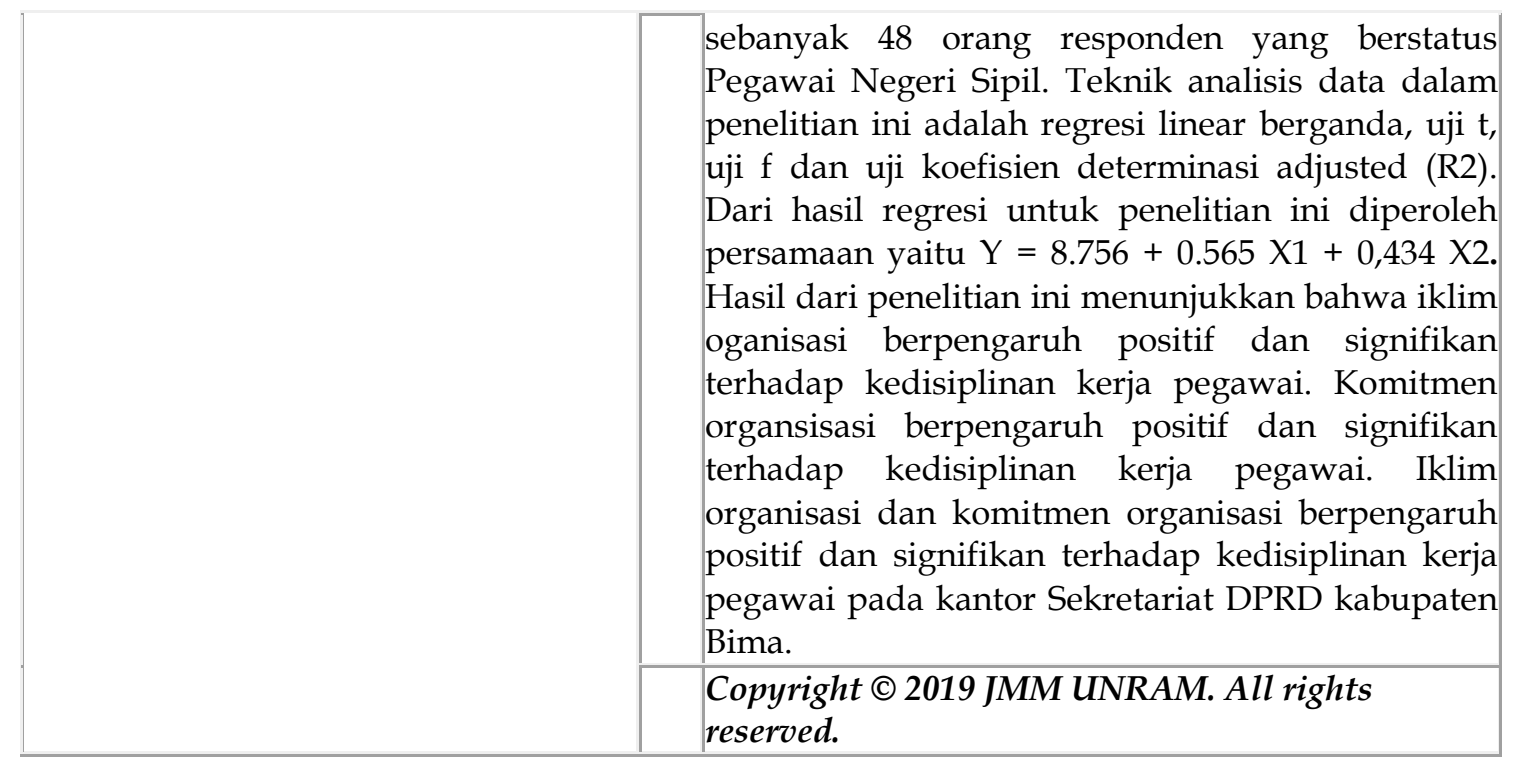

\section{PENDAHULUAN}

Dalam kehidupan sehari-hari, di manapun manusia berada dibutuhkan peraturan dan ketentuan yang akan mengatur serta membatasi setiap kegiatan dan perilakunya. Sementara peraturan-peraturan tersebut tidak akan ada artinya bila tidak disertai dengan sanksi bagi para pelanggarnya. Demikian juga dalam kehidupan suatu organisasi akan sangat membutuhkan ketaatan dari pegawai/karyawannya pada peraturan dan ketentuan yang berlaku pada organisasi tersebut. Dalam suatu organisasi atau instansi, disiplin kerja sangat diperlukan sehingga tujuan organisasi atau instansi tersebut dapat dicapai.Disiplin kerja yang dimaksud antara lain adalah pegawai yang tidak membolos, tidak mudah mangkir, menyelesaikan tugas tepat waktu, serta tidak terlambat masuk kerja.Menurut Rivai (2011) disiplin kerja adalah suatu alat yang digunakan para manajer untuk berkomunikasi dengan pegawai agar bersedia untuk mengubah suatu perilaku serta merupakan upaya untuk meningkatkan kesadaran dan kesediaan individu menaati semua peraturan perusahaan dan norma-norma sosial yang berlaku.

Dari hasil pengamatan awal terlihat tingkat kedisiplinan kerja para pegawai lingkup Sekretariat DPRD Kabupaten Bima dalam hal ini masih terlihat menurun, dimana masih terdapat pegawai yang terlambat masuk kerja, tidak mengikuti apel pagi dan apel sore, istirahat lebih awal dan pulang kerja lebih awal, penyelesaian pekerjaan yang masih kurang baik dan kebiasaan menunda pekerjaan. Selain itu sebagian pegawai di beberapa bidang tidak berada ditempat kerja pada saat jam bekerja, masih adanya pegawai yang tidak masuk kerja dengan alasan yang kurang jelas sehingga masih belum memiliki hari kerja yang penuh, masih ada pegawai yang melakukan kegiatan lain diluar jam kerja dan lebih mementingkan kepentingan pribadi, sehingga terlihat menunjukkan sikap dan perilaku kedisiplinan kerja para pegawai yang menurun.

Melalui wawancara awal dengan beberapa pegawai di lingkup Sekretariat DPRD Kabupaten Bima, menunjukkan bahwa menurunnya tingkat kedisiplinan kerja pegawai diakibatkan karena adanya faktor iklim organisasi dan komitmen organisasi.Iklim organisasi (atau disebut juga suasana organisasi) adalah serangkaian lingkungan kerja disekitar tempat kerja yang berpengaruh terhadap perilaku seseorang dalam melaksanakan pekerjaan.Litwin dan Stringer (2008) Iklim organisasi adalah studi tentang persepsi yang dimiliki tiap individu terhadap berbagai aspek lingkungan dalam organisasi.Iklim kerja 


\section{NATIONALLY ACCREDITED J OURNAL - DECREE NO. 21/E/KPT/2018}

yang dirasakan belum sepenuhnya mendukung aktifitas pekerjaan pegawai dimana tata letak (layout) serta pewarnaan ruangan yang kurang bagus, pegawai masih kurang bersemangat dalam bekerja, adanya hubungan kerja yang dirasakan masih kurang harmonis baik antara bawahan dan pimpinan, maupun hubungan sesama rekan kerja serta kurang memanfaatkanwaktu untuk berdiskusi.

Selain itu sikap komitmen kerja yang ditunjukkan oleh pegawai masih kurang dalam memiliki organisasi tersebut sehingga menyebabkan menurunnya tingkat disiplin kerja pegawai.Luthans, F., (2012) Komitmen organisasi adalah sikap merefleksikan loyatitas karyawan pada organisasi dan proses berkelanjutan dimana anggota organisasi mengekspresikan perhatiannya pada organisasi dan keberhasilan serta kemajuan yang berkelanjutan. Terlihat dari hasil wawancara ketika beberapa pegawai ditanya visi, misi dan nilai-nilai yang dikedepankan dan dia tidak mengetahui secara persis.Ini berarti pegawai belum bias menginternalisasikan tujuan dan nilai-nilai inti organisasi sebagai wujud kebanggaannya terhadap instansi tempatnya bekerja.

Permasalahan diatas diharapkan pimpinan harus mampu memotivasi dan mengontrol perilaku kedisiplinan kerja bawahannya sehingga mereka mentaati terhadap segala peraturan kerja yang berlaku.Pimpinan harus bisa menciptakan kondisi kerja yang nyaman dan sikap komitmen kerja yang tinggi dari bawahannya terhadap organisasi tempatnya bekerja, memberikan reward dan punishment, melakukan pendekatan persuasif dengan bawahannya agar mendapat informasi terkait permasalahan yang menyebabkan menurunnya tingkat disiplin kerja pegawai tersebut.Dengan adanya penelitian ini diharapkan pimpinan kantor Sekretariat DPRD Kabupaten Bima dapat meningkatkan kesidisiplinan kerja para pegawainya.Berdasarkan uraian diatas adapun tujuan dari penelitian ini ingin mengetahui seberapa besar pengaruh iklim organisasi terhadap disiplin kerja pegawai. Pengaruh komitmen organisasi terhadap disiplin kerja pegawai serta mengetahui manakah diantara variabel iklim organisasi dan komitmen organisasi yang memiliki pengaruh dominan terhadap disiplin kerja pegawai pada kantor sekretariat DPRD Kabupaten Bima.

\section{KAJIANPUSTAKA}

\subsection{Kedisiplinan Kerja}

Kedisplinan kerja ialah sikap dan perilaku para pegawai untuk menghormati, menghargai, dan taat terhadap peraturan yang berlaku baik yang tertulis maupun tidak tertulis serta sanggup menjalankannya dan tidak mengelak untuk menerima sanksi apabila ia melanggar tugas dan wewenang yang diberikan kepadanya. Disiplin adalah perilaku seseorang yang sesuai dengan peraturan, prosedur kerja yang ada atau disiplin adalah sikap, tingkah laku dan perbuatan yang sesuai dengan peraturan dari organisasi baik tertulis maupun tidak tertulis.Edy, S., (2016).

Menurut Hasibuan (2015) Kedisiplinan kerja adalah kemampuan kerja seseorang untuk secara teratur, tekun, terus-menerus, dan bekerja sesuai dengan aturan-aturan yang berlaku dengan tidak melanggar aturan-aturan yang sudah ditetapkan. Hasibuan (2015) mengatakankedisiplinan adalah kunci keberhasilan suatu perusahaan dalam mencapai tujuannya.

Ada beberapa indikator Kedisiplinankerja menurut Hasibuan (2015) yaitu:

a. Tujuan dan kemampuan

b. Teladan Pimpinan

c. Balas jasa

d. Keadilan 
e. Waskat

f. Sanksi hukuman

g. Ketegasan pimpinan

h. Hubungan kemanusiaan

\subsection{Iklim Organisasi}

Iklim Organisasi diartikan sebagai kondisi psikososial yang dialami oleh para anggota organisasi dalam lingkungan kerja masing-masing serta merupakan faktor stimulan yang secara langsung maupun tidak langsung berpengaruh terhadap persepsi perasaan pegawai diantaranya dapat menyangkut rasa aman dan nyaman, keakraban hubungan bawahan dengan atasan dan berbagai persoalan kontekstual lainnya.Kusjanah (2008) mengatakan bahwa Iklim organisasi juga berperan sebagai sarana psikologis yang berpengaruh terhadap perilaku anggota organisasi, terbentuk sebagai hasil tindakan organisasi dan interaksi antara anggota organisasi.

Kusjanah (2008) Iklim organisasi merupakan lingkungan internal suatu organisasi yang dialami oleh anggota-anggotanya, mempengaruhi perilaku serta dapat tergambar dalam seperangkat karakteristik atau atribut khusus dari organisasi.

Adapun Indikator iklim menurut Robbins, SP \& Judge, (2015) yaitu :

1. Conformity (Kesesuaian)

2. Responsibility (tanggungjawab)

3. Standart (Standar)

4. Reward (Penghargaan)

5. Clarity (Kejelasan)

6. Team Spirit (Semangat Tim)

\subsection{Komitmen Organisasi}

Komitmen organisasi didefinisikan sebagai sebagai kekuatan psikologis individu untuk mengidentifikasikan dirinya dengan organisasinya, menerima visi, misi dan tujuan organisasi serta selalu menginginkan dirinya bertahan untuk menjadi bagian dari organisasi.

Robbins, SP \& Judge, (2015) Komitmen organisasi adalah keadaan dimana seorang karyawan memihak organisasi tertentu serta tujuan-tujuan dan keinginannya untuk mempertahankan keanggotaan dalam organisasi tersebut. Robbins,SP\& Judge, (2015) Komitmen organisasi dibedakan atas tiga indikator menurut yaitu :

1. Komitmen afektif, Perasaan emosional untuk organisasi dan keyakinan dalam nilainilainya.

2. Komitmen berkelanjutan, nilai ekonomi yang dirasakan dari bertahan dengan sebuah organisasi bila dibandingkan dengan meninggalkan organisasi tersebut.

3. Komitmen normatif, komitmen untuk bertahan dengan organisasi untuk alasan-alasan moral atau etis.

\subsection{Tinjauan Penelitian Terdahulu}

D.L.Singal.,Adolfina.,L.O.H.Dotulong.,(2018)Analisis Pengaruh Iklim Organisasi Dan Komitmen Organisasi Terhadap Disiplin Kerja Pegawai (Studi Di Bank Mandiri Area Manado). Berdasarkan hasil pengujian hipotesis menunjukkan bahwa iklim organisasi dan komitmen organisasi berpengaruh secara simultan dan parsial terhadap disiplin kerja pegawai di Bank Mandiri Area Manado.

Gabriel Kawas Tarigan (2016) Pengaruh Iklim Organisasi Dan Komitmen Karyawan Terhadap Kedisiplinan Karyawan Pada Perusahaan Daerah Air Minum 


\section{NATIONALLY ACCREDITED J OURNAL - DECREE NO. 21/E/KPT/2018}

Tirta Kencana Samarinda.Tujuan penelitian ini adalah untuk mengetahui pengaruh iklim organisasi dan komitmen organisasi terhadap kedisiplinan kerja pada karyawan wanita PDAM Tirta Kencana Samarinda.Berdasarkan hasil pembahasan terdapat pengaruh yang signifikan antara iklim organisasi terhadap kedisiplinan kerja pada karyawan PDAM Tirta Kencana.Terdapat pengaruh yang signifikan antara komitmen organisasi terhadap kedisiplinan kerja pada karyawan PDAM Tirta Kencana.Terdapat pengaruh yang signifikan antara iklim organisasi dan komitmen organisasi terhadap kedisiplinan kerja pada karyawan PDAM Tirta Kencana.

Edi Setiawan., (2018) Pengaruh Gaya Kepemimpinan Dan Komitmen Organisasi Terhadap Disiplin Kerja Dengan Kepuasan Kerja Sebagai Variabel Intervening(pada karyawan PT. PLN (persero) Area Surakarta). Penelitian ini betujuan untuk menganalisis faktor - faktor yang dapat berpengaruh pada kepuasan dan disiplin kerja karyawan yang ada di PT. PLN (Persero) AREA Surakarta. Model penelitian yang akan digunakan dalam penelitian ini adalah model struktur berjenjang dan untuk menguji hipotesis yang diajukan digunakan teknik analisis SEM (Structural Equation Modelling) yang dioperasikan melalui program Smart PLS 2.0 M3. Berdasarkan hasil Analisis yang dilakukan menunjukkan hasil bahwa Gaya kepemimpinan tidak berpengaruh positif terhadap disiplin kerja, Komitmen organisasi berpengaruh positif terhadap disiplin kerja, Gaya kepemimpinan berpengaruh positif terhadap kepuasan kerja, Komitmen organisasi berpengaruh positif terhadap kepuasankerja dengan, dan Kepuasan kerja berpengaruh positif terhadap disiplin kerja.

\subsection{Kerangka Pikir Penelitian}

Adapun kerangka pikir penelitian sebagai berikut :

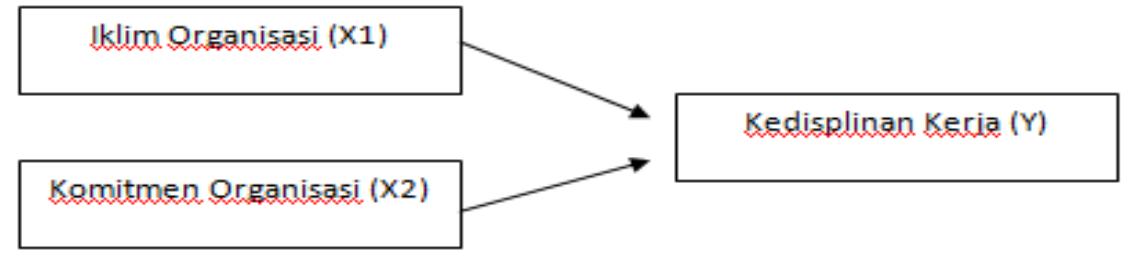

Berdasarkan kerangka konseppenelitian, maka hipotesis penelitianadalah sebagai berikut:

$\mathrm{H} 1$ = Iklim Organisasi berpengaruh positif dan signifkan terhadap Kedisiplinan Kerja Pegawai pada Kantor Sekretariat DPRD Kabupaten Bima.

$\mathrm{H} 2$ = Komitmen Organisasi berpengaruh positif dan signifkan terhadap Kedisiplinan Kerja Pegawai pada Kantor Sekretariat DPRD Kabupaten Bima

\section{METODE PENELITIAN}

Jenis penelitian ini adalah asosiatif kausalitas.Penelitian ini bertujuan untuk mengetahui seberapa besar pengaruh secara parsial iklim organisasi terhadap disiplin kerja pegawai dan Pengaruh secara parsial komitmen organisasi terhadap disiplin kerja pegawai.Metode pengumpulan data yang digunakan dalam penelitian ini adalah observasi, wawancara, kuisioner dan dokumentasi.Populasidalam penelitian ini adalah seluruh pegawai Negeri Sipil (PNS) yang berada pada kantor Sekretariat DPRD Kabupaten Bima sejumlah 48 orang pegawai. Teknik pengambilan sampel yang digunakan dalam penelitian ini adalah tekhnik sensus,Jenis datayang digunakan dalam penelitian ini adalah data kuantitatif yaitu data yang berbentukangka-angka atau data kualitatif yang 
diangkakan.Teknik analisis data dalam penelitian ini menggunakan regresi linear berganda, uji $t$, uji $f$ dan uji koefisien determinasi adjusted (R2) dengan bantuan SPSS 20 for windows.

\section{HASIL PENELITIAN DAN PEMBAHASAN}

\subsection{Karakteristik Responden}

1) Deskripsi Responden Berdasarkan Jenis Kelamin

Tabel 4.1 Deskripsi Responden Berdasarkan Jenis Kelamin.

\begin{tabular}{|c|l|c|c|}
\hline No. & \multicolumn{1}{|c|}{ Jenis Kelamin } & Frekuensi & Persentase (\%) \\
\hline 1 & Laki - Laki & 33 & $68 \%$ \\
\hline 2 & Perempuan & 15 & $31 \%$ \\
\hline \multicolumn{2}{|c|}{ Jumlah } & 48 & $100 \%$ \\
\hline
\end{tabular}

Sumber : Data Primer Diolah, 2019

Dari tabel 4.1 tersebut dapat dilihat bahwa responden sebagian besar berjenis kelamin laki-laki, yaitu sebanyak 33 orang Pegawai Negeri Sipil padaKantor Sekretariat DPRD Kabupaten Bimadan sisanya adalah responden yang berjenis kelamin perempuan, yaitu sebanyak 15 orang Pegawai Negeri Sipil. Jadi pada penelitian ini lebih dominan responden laki-laki dari pada perempuan yang memberikan tanggapan terhadap pertanyaan pada kuesioner.

2) Deskripsi Responden Berdasarkan Tingkat Pendidikan

Tabel 4.2 Deskripsi Responden Berdasarkan Tingkat Pendidikan

\begin{tabular}{|c|c|c|c|}
\hline No & Pendidikan & Jumlah (orang) & Prosentase (\%) \\
\hline 1. & SD & 0 & $0 \%$ \\
\hline 2. & SMP & 0 & $0 \%$ \\
\hline 3. & SMA & 16 & $33 \%$ \\
\hline 4. & S & 30 & $62 \%$ \\
\hline 5. & S 2 & 2 & $5 \%$ \\
\hline 6. & S3 & 0 & $0 \%$ \\
\hline \multicolumn{2}{r|}{ JUMLAH } & 48 & $100 \%$ \\
\hline
\end{tabular}

Sumber : Data Diolah, 2019

Dari tabel 4.2 tersebut dapat dilihat bahwa responden sebagian besar berpendidikan Sarjana S1, yaitu sebanyak 30orang Pegawai Negeri Sipil pada Kantor Sekretariat DPRD Kabupaten Bimaatau $62 \%$. Responden yang mempunyai tingkat pendidikanSMA yaitu sebanyak 16 orang Pegawai Negeri Sipil pada Kantor Sekretariat DPRD Kabupaten Bimaatau $33 \%$.Responden yang mempunyai tingkat pendidikan S2 yaitu sebanyak 2 orang Pegawai Negeri Sipil pada Kantor Sekretariat DPRD Kabupaten Bima atau 5 \%.Jadi responden yang banyak memberikan tanggapan yaitu pada tingkat pendidikan S1 (Strata 1). Terlihat responden yang memiliki tingkat pendidikan sarjana yang akan lebih dominan dalam penilaian kedisiplinan kerja.

3) Deskripsi Responden Berdasarkan Umur Responden

Tabel 4.3 Deskripsi Responden Berdasarkan Umur Responden.

\begin{tabular}{|c|c|c|c|}
\hline No & Umur (tahun) & Jumlah Responden & Prosentase \\
\hline 1 & $<25$ & 0 & $0 \%$ \\
\hline 2 & $26-35$ & 0 & $0 \%$ \\
\hline 3 & $36-45$ & 28 & $58 \%$ \\
\hline 4 & $>46$ & 20 & $42 \%$ \\
\hline
\end{tabular}




\begin{tabular}{|c|c|c|}
\hline JUMLAH & 48 & $100 \%$ \\
\hline
\end{tabular}

\section{Sumber : Data Diolah, 2019}

Berdasarkan tabel 4.3 tersebut dapat dilihat bahwa responden terbanyak adalah pada kelompok umur 36-45 tahun yaitu sebanyak 28orang Pegawai Negeri Sipil pada Kantor Sekretariat DPRD Kabupaten Bima atau 58\%. Sedangkan kelompok umur $>46$ tahun yaitu sebanyak 20 orang Pegawai Negeri Sipil pada Kantor Sekretariat DPRD Kabupaten Bima atau $42 \%$.Hal ini menunjukkan kedisiplinan kerja banyak di laksanakan dan dijalankan oleh pegawai yang berumur sekitar 36-45 tahun.

4) Deskripsi Responden Berdasarkan Lama Kerja.

Tabel 4.4 Deskripsi Responden Berdasarkan Lama Kerja.

\begin{tabular}{|c|c|c|c|}
\hline No & Lama Kerja (Tahun) & Jumlah (Orang) & Prosentase $(\%)$ \\
\hline 1 & $<5$ & 0 & $0 \%$ \\
\hline 2 & $6-15$ & 32 & $66 \%$ \\
\hline 3 & $16-25$ & 8 & $17 \%$ \\
\hline 4 & $>26$ & 8 & $17 \%$ \\
\hline & TOTAL & 48 & $100 \%$ \\
\hline
\end{tabular}

Sumber : Data Diolah, 2019

Berdasarkan tabel 4.4 tersebut dapat dilihat bahwa responden terbanyak adalah pada kelompok pegawai dengan masa kerja 6-15 tahun sebanyak 32Pegawai Negeri Sipilatau $66 \%$.Kelompok pegawai dengan masa kerja 16-25 tahun sebanyak 8 pegawaiatau $17 \%$.Kelompok pegawai dengan masa kerja >26 tahun sebanyak 8 pegawaiatau $17 \%$.Sedangkan kelompok umur yang paling sedikit adalah dengan masa kerja $<5$ tahun yaitu sebanyak 0 orang atau $0 \%$. Hal ini menunjukkan bahwa jumlah pegawai berdasarkan masa kerja yang ada pada Kantor Sekretariat DPRD Kabupaten Bima 6-15 tahun masa kerja yang akan banyak memberikan gambaran terhadap kedisiplinan kerja pegawai.

\subsection{Persamaan regresi}

Selanjutnya untuk mengetahui apakah hipotesis yang diajukan dalam penelitian ini diterima atau ditolak maka akan dilakukan pengujian hipotesis dengan menggunakan uji t. Hasil pengujian hipotesis dijelaskan sebagai berikut:

Tabel 4.5 Hasil Persamaan Regresi

\begin{tabular}{|c|c|c|c|c|c|}
\hline \multicolumn{6}{|c|}{ Coefficientsa } \\
\hline Model & $\begin{array}{r}\text { Unstanc } \\
\text { Coeff }\end{array}$ & $\begin{array}{l}\text { ardized } \\
\text { cients }\end{array}$ & $\begin{array}{c}\text { Standardized } \\
\text { Coefficients }\end{array}$ & $\mathrm{t}$ & Sig. \\
\hline & $\mathrm{B}$ & Std. Error & Beta & & \\
\hline (Constant) & 8.756 & 4.387 & & 1.996 & .052 \\
\hline Iklim Organisasi & .565 & .167 & .428 & 3.385 & .001 \\
\hline Komitmen Organisasi & .434 & .159 & .345 & 2.728 & .009 \\
\hline
\end{tabular}

\section{Sumber: Data Diolah 2019}

Dari hasil analisis regresi dapat diketahui persamaan regresi berganda sebagai berikut: $Y=8,756+0,565 \mathrm{X}_{1}+0,434 \mathrm{X}_{2}$

Berdasarkan persamaan tersebut, maka dapat dijelaskan sebagai berikut:

a. Nilai konstanta sebesar 8,756 dapat diartikan apabila variabel Iklim Organisasi dan Komitmen Organisasi dianggap nol, maka Kedisiplinan Kerja akan sebesar 8,756.

b. Nilai koefisien beta pada variabel Iklim Organisasi sebesar 0, 565 artinya setiap perubahan variabel Iklim Organisasi $\left(X_{1}\right)$ sebesar satu satuan maka akan mengakibatkan perubahan Kedisiplinan Kerja sebesar 0, 565 satuan, dengan asumsi-asumsi yang lain adalah tetap. Peningkatan satu satuan pada variabel Iklim Organisasi akan meningkatkan Kedisiplinan Kerja sebesar 0,134 satuan. 
c. Nilai koefisien beta pada variabel Komitmen Organisasi sebesar 0,434 artinya setiap perubahan variabel Komitmen Organisasi $\left(X_{2}\right)$ sebesar satu satuan, maka akan mengakibatkan perubahan Kedisiplinan Kerja sebesar 0,434 satuan, dengan asumsiasumsi yang lain adalah tetap. Peningkatan satu satuan pada variabel Komitmen Organisasiakan meningkatkan Kedisiplinan Kerja sebesar 0,434 satuan.

\subsection{Uji Koefisien determinasi ( $\left.R^{2}\right)$}

Uji Koefisien determinasi ( $\mathrm{R}^{2}$ ) adalah untuk mengukur seberapa besar pengaruh variabel independen terhadap variabel dependen. Nilai koefisien determinasi menggunakan $R$ Square.Berikut Hasil uji koefisien determinasi dapat dilihat pada :

Table 4.6.Hasil Koefisien determinasi ( $\left.\mathbf{R}^{2}\right)$

\begin{tabular}{|c|c|c|c|c|}
\hline Model & $\mathrm{R}$ & R Square & Adjusted R Square & $\begin{array}{l}\text { Std. Error of the } \\
\text { Estimate }\end{array}$ \\
\hline 1 & $.667^{a}$ & .445 & .420 & 2.454 \\
\hline
\end{tabular}

Sumber: Data Diolah 2019

Dari data diatas,dapat diketahui bahwa koefisien determinasi (Nilai R Square) yang diperoleh sebesar 0,445. Hali ini menunjukkan bahwa variable Iklim organisasi dan Komitmen Organisasi hanya mempengaruhi sebesar 44,5\% terhadap Disiplin Kerja Pegawai. Sedangkan sisanya $55.5 \%$ dipengaruhi oleh variabel lain yang tidak diteliti dalam penelitian ini.

\subsection{Pengujian Hipotesis}

Selanjutnya untuk mengetahui apakah hipotesis yang diajukan dalam penelitian ini diterima atau ditolak maka akan dilakukan pengujian hipotesis dengan menggunakan uji t. Hasil pengujian hipotesis dijelaskan sebagai berikut:

Tabel 4.7 Hasil Persamaan Regresi

\begin{tabular}{|c|c|c|c|c|c|}
\hline \multicolumn{6}{|c|}{ Coefficients ${ }^{a}$} \\
\hline \multirow[t]{2}{*}{ Model } & $\begin{array}{l}\text { Unstanc } \\
\text { Coeff }\end{array}$ & $\begin{array}{l}\text { ardized } \\
\text { cients }\end{array}$ & $\begin{array}{c}\text { Standardized } \\
\text { Coefficients }\end{array}$ & $\mathrm{t}$ & Sig. \\
\hline & $\mathrm{B}$ & Std. Error & Beta & & \\
\hline (Constant) & 8.756 & 4.387 & & 1.996 & .052 \\
\hline Iklim Organisasi & .565 & .167 & .428 & 3.385 & .001 \\
\hline Komitmen Organisasi & .434 & .159 & .345 & 2.728 & .009 \\
\hline
\end{tabular}

Sumber: Data Diolah 2019

1) Pengujian Hipotesis Pertama.

Hasil statistik uji $t$ untuk variabel diperoleh nilai $t_{\text {hitung }}$ sebesar 3,385 dengan nilai $t_{\text {tabel }}$ sebesar 2,014 $(3,385>2,014)$ dengan nilai signifikansi sebesar 0,001 lebih kecil dari 0,05 $(0,001<0,05)$, yang artinya hipotesis menyatakan bahwa "Iklim Organisasiberpengaruh positif dan signifikan terhadap kedisiplinan kerja pegawai". Apabila suatu organisasi ingin meningkatkan kedisiplinan kerja pegawainya maka salah satunya harus bias menciptakan iklimorganisasi serta suasana kerja yang kondusif dan nyaman. Dengan menciptakan suasana kerja yang nayaman dan kondusif maka sikap dan perilaku kedisiplinan kerja para pegawai dapat meningkat.

Dengan demikian Ha diterima dan Ho ditolak.

\section{2) Pengujian Hipotesis Kedua.}

Hasil statistik uji $t$ untuk variabel diperoleh nilai $t_{\text {hitung }}$ sebesar 2,728 dengan nilai $t_{\text {tabel }}$ sebesar 2,014 (2,728> 2,014) dengan nilai signifikansi sebesar 0,009 lebih besar dari 0,05 
$(0,009<0,05)$, yang artinya hipotesis menyatakan bahwa "Komitmen Organisasiberpengaruh positif dan signifikan terhadap Disiplin Kerja". Sikap komitmen kerja yang baik akan menimbulkan kedisiplinan kerja karena dengan memiliki sikap yang komitmen terhadap organisasi maka para pegawai akan menganggap bahwa organisasi tersebut merupaka bagian dari kehidupannya kerjanya.Dengan demikian Ha diterima dan Ho ditolak.

\section{KESIMPULAN}

Berdasarkan hasil pembahasan maka dapat ditarik kesimpulan bahwa iklim organisasi berpengaruh positif dan signifikan terhadap kedisiplinan kerja pegawai pada kantorSekretariat DPRD Kabupaten Bima. Komitmen organisasi berpengaruh positif dan signifikan terhadap kedisiplinan kerja pegawai pada kantor Sekretariat DPRD Kabupaten Bima. Dari analisis koefisien determinasi diketahui bahwaiklim organisasi dan komitmen organisasi mempengaruhi kedisiplinan kerja pegawai pada kantor Sekretariat DPRD Kabupaten Bima sebesar 44,5\%.

Berdasarkan kesimpulan diatas, betapa pentingnya menciptakan kedisiplinan kerja pegawai pada kantor Sekretariat DPRD Kabupaten Bima. Dalam hal ini pendekatan melalui komunikasi persuasif maupun komunikasikoersif harus tetap dipertahankan dan ditingkatkan lagi oleh para pimpinan pada kantor Sekretariat DPRD Kabupaten Bima secara terus menerus dalam suasana yang makin akrab dan penuh persaudaraan. Apabila pendekatan persuasif dan pendekatan koersif di terapkan secara baik oleh pimpinan, maka akan membentuk serta menciptakan sikap kedisiplinan bagi para pegawai dalam bekerja.

\section{DAFTAR KEPUSTAKAAN}

D.L.Singal.,Adolfina.,L.O.H.Dotulong.,(2018). Analisis Pengaruh Iklim Organisasi Dan Komitmen Organisasi Terhadap Disiplin Kerja Pegawai (Studi Di Bank Mandiri Area Manado). Jurnal EMBA Vol.6 No.4 September 2018, Hal. 2678 - 2687

Edy, Sutrisno. 2016. Manajemen Sumber Daya Manusia.Kencana Prenada Media Group, Jakarta

Edi Setiawan, 2018.Pengaruh Gaya Kepemimpinan Dan Komitmen Organisasi Terhadap Disiplin Kerja Dengan Kepuasan Kerja Sebagai Variabel Intervening(pada karyawan PT. PLN (persero) Area Surakarta).Prima Ekonomika-Vol.9, No. 1, Maret 2018

Hasibuan, Malayu. 2015. Manajemen Sumber Daya Manusia. Penerbit: PT. Bumi Aksara, Jakarta.

Kusjanah (2008, dalam Gabriel Kawas Tarigan, 2016) Pengaruh Iklim Organisasi dan Komitmen Karyawan Terhadap Kedisiplinan Karyawan Pada Perusahaan Daerah Air Minum Tirta Kencana Samarinda.eJournal Psikologi, 2016,4 (4) 472-480 ISSN 2477-2674, ejournal Psikologi.fisip-unmul.ac.id

Litwin dan stringer (2008, dalam Gabriel Kawas Tarigan, 2016). Pengaruh Iklim Organisasi dan Komitmen Karyawan Terhadap Kedisiplinan Karyawan Pada Perusahaan Daerah Air Minum Tirta Kencana Samarinda.eJournal Psikologi, 2016,4 (4) 472-480 ISSN

Luthans, Fred. 2012. Perilaku Organisasi. Yogyakarta: Penerbit Andi.

Rivai, 2011.,Manajemen sumber daya manusia untuk perusahaan. Bandung: PT. Remaja Rosda Karya.

Robbins, SP \& Judge, 2015, Perilaku Organisasi. Jakarta: Salemba Empat. 